\title{
Case Study: West Point Terminal/Southern Railway
}

Clifford F. Thies, Shenandoah University, USA

\begin{abstract}
This real world case study investigates how priority of claim interacts with the rules of bankruptcy to preserve the values of securities issued by corporations in the context of one of the most famous reorganizations of all times. (However, many facts have been changed to facilitate classroom use.) The case does not presume prior knowledge of the rules of bankruptcy. It is recommended for a senior-level undergraduate or MBA course in financial management.
\end{abstract}

Keywords: bankruptcy; reorganization; priority of claim; West Point Terminal; Southern Railway; J.P. Morgan

\section{INTRODUCTION}

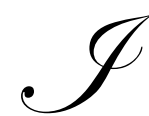

n 1892, the Richmond \& West Point Terminal Railway and Warehouse Co., along with several of its subsidiaries, defaulted on interest obligations, and the president of the company, John H. Inman, was appointed its receiver. During the next two years, two factions vied for control of the company, one representing the incumbent owners, directors and managers, and the other representing prospective ownership organized by the investment banking house of J.P. Morgan (Daggart, 1908; Klein, 1970).

The Richmond \& West Point Terminal Railway \& Warehouse Co. ("the Terminal Co.") was organized in 1880 to enable the Richmond \& Danville RR ("the R\&D") to consolidate its control of a system of railroads in the southeast portion of the United States, generally running from Alexandria and Richmond, VA, to Atlanta, GA (see Figure 1).

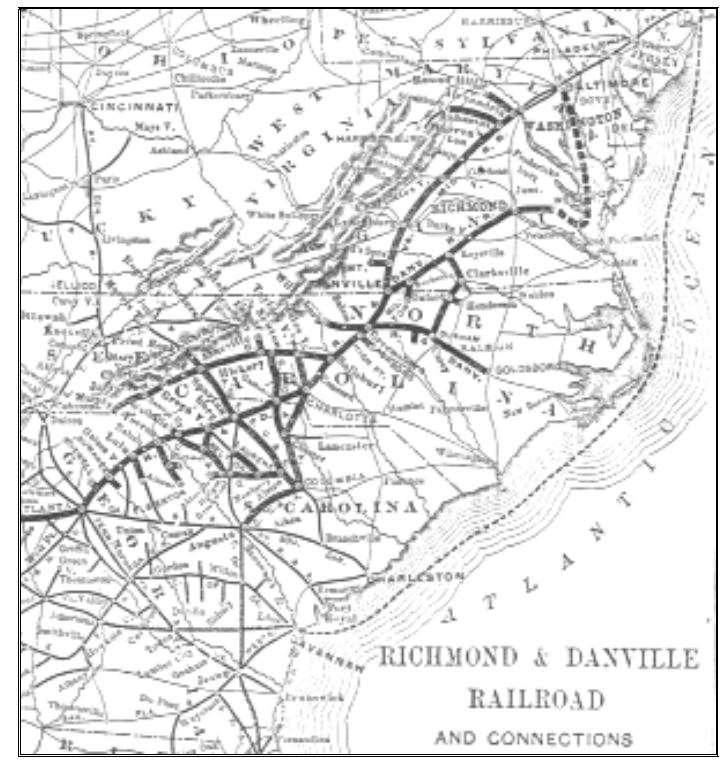

Figure 1: The Richmond \& Danville RR, circa 1892 
The R\&D was prohibited by its charter from owning stocks in companies with which it did not directly connect, whereas the Terminal Co. was empowered by its charter to own stocks in railroad companies in the states of North Carolina, South Carolina, Tennessee, Kentucky, Georgia, Alabama, Mississippi, and others. At about the same time, two other north-south systems were being organized in the southeast: the Atlantic Coast and the Seaboard systems. In all three cases, northern capitalists were involved, gaining control of short lines through stock purchases and leases of originally independent lines, constructing connecting lines, where necessary, and increasing the capacity of roads through reconstruction and by adding locomotives, cars, signaling equipment, and so forth (Stover, 1955). By 1883, the R\&D and the Terminal Co. owned, leased and otherwise controlled some 2,500 miles of railroad (refer to the following chart).

Richmond \& Danville RR/Richmond \& West Point Terminal Ry \& Warehouse Co. 1883

Richmond \& Danville RR (Richmond to Danville VA) 152 miles

Piedmont RR (Danville VA to Greensboro NC)

North Carolina RR (Goldsboro via Greensboro to Charlotte NC)

49 miles

Atlanta \& Charlotte Air-Line Ry (Charlotte NC to Atlanta GA) 233 miles

Virginia Midland Ry (Alexandria via Charlottesville to Danville VA) 339 miles

Western North Carolina RR (Salisbury to Paint Rock NC) 237 miles

Charlotte, Columbia \& Augusta RR (Charlotte NC via Columbia SC to Augusta GA) 206 miles

Columbia \& Greenville RR

191 miles

Georgia Pacific Ry (Atlanta GA to Greenville MS) .......

65 miles

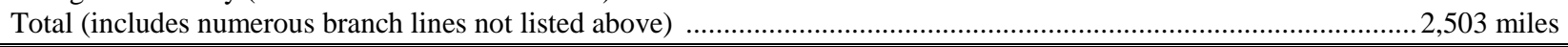

When the Terminal Co. was organized in 1880 , the $R \& D$ acquired a large majority of its stock. The R\&D paid for the shares of the Terminal Co. in part with its own stock. By 1883, the R\&D owned $\$ 7.51$ million of the $\$ 15$ million of stock outstanding of the Terminal Co. (i.e., a bare majority); and, the Terminal Co. owned about 10 percent of the $\$ 5$ million of stock outstanding of the R\&D (a non-controlling minority).

By 1886, however, a conflict developed between the R\&D and the Terminal Co. Management of the R\&D attempted to wrest control of the railroads owned by the Terminal Co. by leasing them, effectively relegating the Terminal Co. to the status of an empty shell. The R\&D then sold off its stake in the Terminal Co. (see Figure 2).

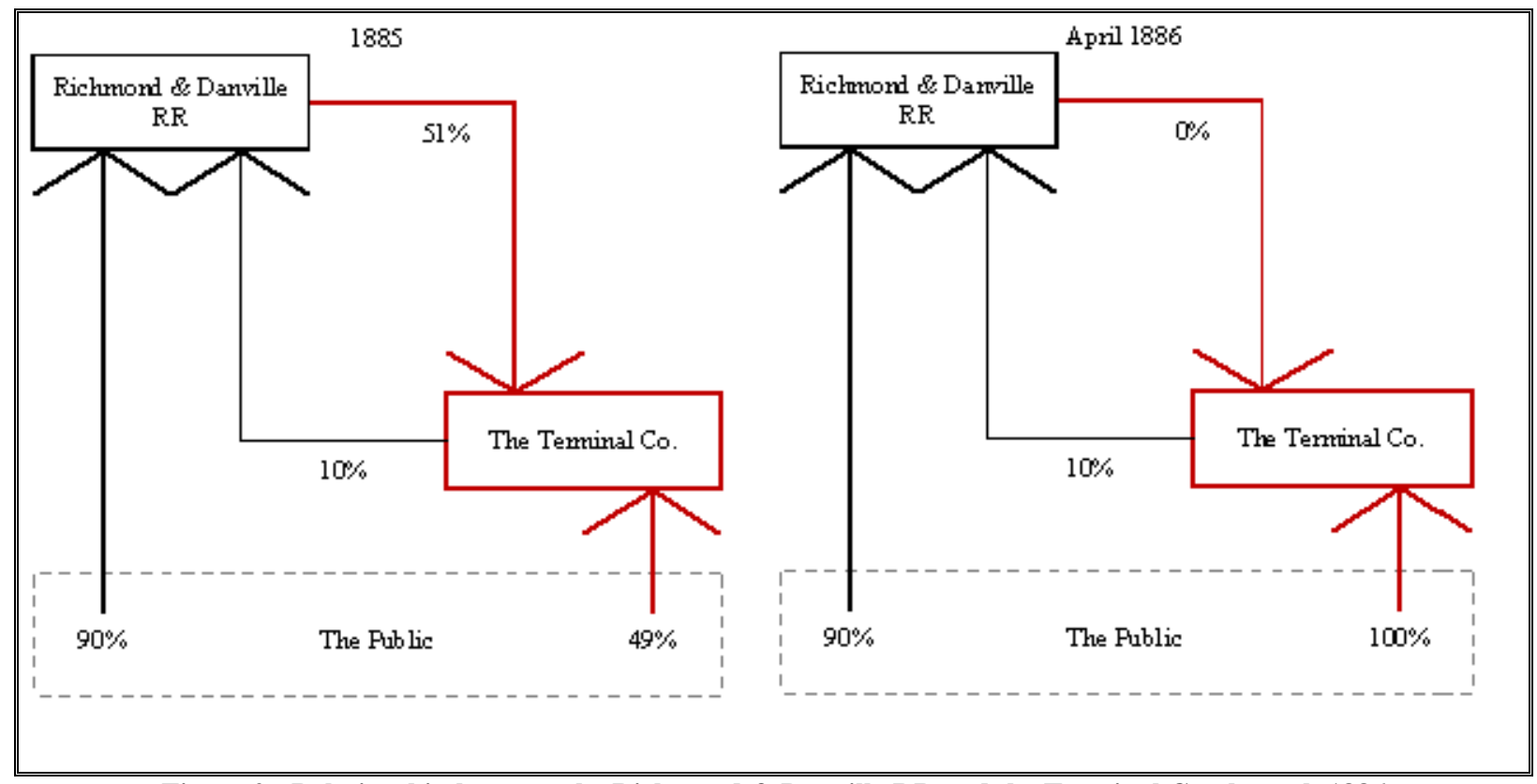

Figure 2: Relationship between the Richmond \& Danville RR and the Terminal Co. through 1886 

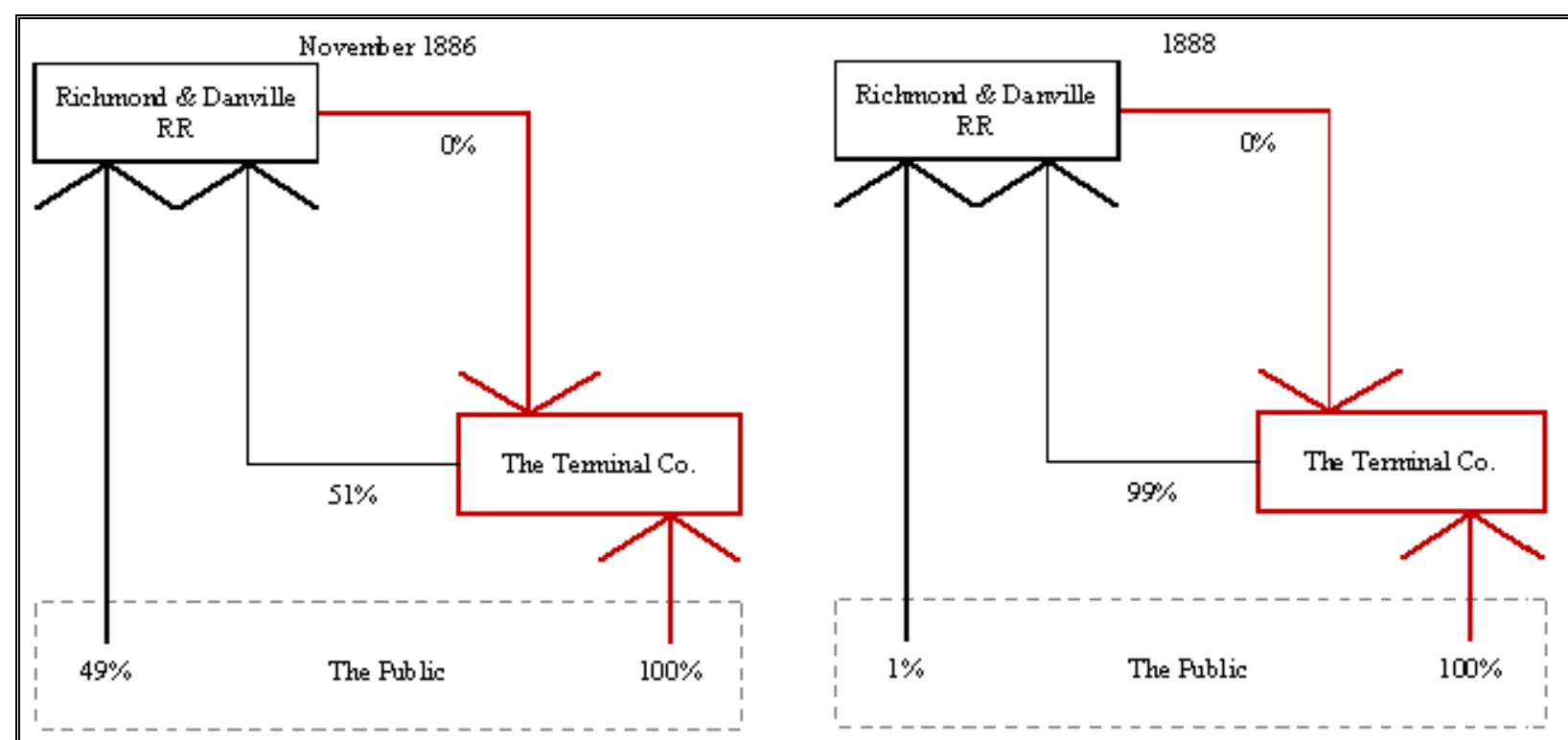

Figure 3: Relationship between the Richmond \& Danville RR and the Terminal Co. following 1886

The Terminal Co. responded by acquiring another 41 percent of the stock of the R\&D, bringing its total stake in the R\&D to 51 percent. The Terminal Co. raised the necessary funds by issuing new preferred and common stock. During the contest for control of the R\&D, the market value of its stock was raised temporarily to $\$ 200$ per share (as compared to its par value of $\$ 100$ per share). After it gained control of the R\&D, the Terminal Co. acquired almost all the remaining stock of the R\&D, thereby consolidating its control over the system (see Figure 3).

During the next few years, the Terminal Co. conducted an ambitious program of expansion by acquisition. In 1887, the company acquired control of the East Tennessee, Virginia \& Georgia Ry, about 1,600 miles in length, shortly following its reorganization. The East Tennessee generally operated on the west slope of the Appalachian Mountains, roughly parallel to the R\&D, from Bristol, TN, to Mobile, AL, with a line to the Atlantic Ocean from Macon, GA, to Brunswick, GA. In 1888, the Terminal Co. acquired control of the Central RR of Georgia, about 2,300 miles in length, mostly operating within the state of Georgia. Together with other acquisitions, by 1889 , the Terminal Co. was operating one of the largest railroad systems in the country (see the following chart).

Richmond \& West Point Terminal Ry \& Warehouse Co. 1889

Richmond \& Danville system 3,090 miles

East Tennessee system ...... 1,628 miles

Central of Georgia system 2,303 miles Total 7,021 miles

Consolidating its control over the R\&D, obtaining control over the East Tennessee and Central of Georgia systems, other acquisitions, and various improvements to its roads saddled the Terminal Co. and its subsidiaries with very large interest expense on bonds and rental expense on leased roads. Fortunately, through 1891, revenue and income of the Terminal Co. and its subsidiaries were generally rising, as is illustrated in the income statements of the R\&D, shown in Tables 1 to 3 (Poor, 1884-1895). Strength in revenue and income enabled the Terminal Co. and its subsidiaries to meet their heavy fixed expenses and as well as make dividend payments on at least some of the stocks of its subsidiaries, including the R\&D in 1889. 


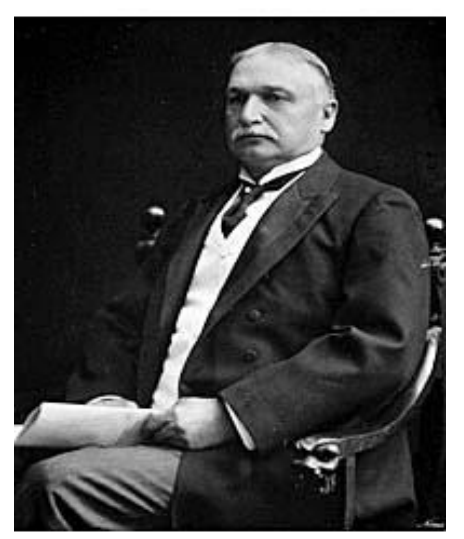

By 1889, John H. Inman, originally of Georgia, had established himself as firmly in charge of the Terminal Co. He was president of both it and the R\&D, and was joined on the boards of directors of the two companies by his brother Samuel Inman and several key northern capitalists, the most prominent of which was Jay Gould, "the scion of Wall Street." Mr. Inman had himself profited very handsomely from his control of the Terminal Co., having had a significant interest in the Central of Georgia at the time of its sale to the Terminal Co. To maintain his control over the vast system of roads encompassed by the Terminal Co., almost of Mr. Inman's personal wealth was invested in the junior securities of the Terminal Co., such as third mortgage bonds, income bonds, and preferred and common stocks, securities whose market values depended critically on the ability of the Terminal Co. and its subsidiaries to continue to grow its revenue and income. But, these securities could easily become worthless if a downturn in business forced the company to default on its obligations.

Table 1: Income Statements for years ending June $30^{\text {th }}$

\begin{tabular}{|c|c|c|c|c|c|c|}
\hline & 1883 & 1884 & 1885 & 1886 & 1887 & 1888 \\
\hline Revenue-Passengers & 909,564 & 955,184 & 985,709 & 998,023 & $1,017,312$ & $1,190,604$ \\
\hline Revenue-Freight & $2,606,225$ & $2,511,760$ & $2,660,755$ & $2,646,434$ & $2,716,699$ & $2,844,116$ \\
\hline Revenue-Mail, etc. & 290,003 & 333,437 & 334,891 & 348,024 & 418,981 & 475,528 \\
\hline Total Revenue & $3,805,792$ & $3,800,381$ & $3,981,355$ & $3,992,481$ & $4,152,992$ & $4,510,248$ \\
\hline Maintenance of Road & & & 486,128 & 457,911 & 508,515 & 555,582 \\
\hline Maintenance of Equipment & & & 831,185 & 748,218 & 815,731 & 928,630 \\
\hline Other Operating Expenses & $2,218,853$ & $2,204,139$ & 914,173 & 915,424 & 963,611 & $1,085,513$ \\
\hline Operating Expenses & $2,218,853$ & $2,204,139$ & $2,231,486$ & $2,121,553$ & $2,287,857$ & $2,569,725$ \\
\hline Operating Income & $1,586,939$ & $1,596,242$ & $1,749,869$ & $1,870,928$ & $1,865,135$ & $1,940,523$ \\
\hline Other Income (Loss) & 56,676 & 68,606 & 17,793 & 19,547 & 202,170 & 257,061 \\
\hline Total Income & $1,643,615$ & $1,664,848$ & $1,767,662$ & $1,890,475$ & $2,067,305$ & $2,197,584$ \\
\hline Taxes* & 0 & 0 & 0 & 0 & 0 & 0 \\
\hline Rents & 979,814 & 979,654 & 879,654 & 879,654 & 879,654 & 880,104 \\
\hline Interest & 415,566 & 433,836 & 562,890 & 567,864 & 600,328 & 684,058 \\
\hline Other fixed charges $* *$ & 135,678 & 172,113 & 40,553 & 20,140 & 1,536 & $(63,368)$ \\
\hline Fixed Charges & $1,531,058$ & $1,585,603$ & $1,483,097$ & $1,467,658$ & $1,481,518$ & $1,500,794$ \\
\hline Dividends & 0 & 0 & 0 & 0 & 0 & 0 \\
\hline \multirow[t]{2}{*}{ Surplus } & 112,557 & 79,245 & 284,565 & 422,817 & 585,787 & 696,790 \\
\hline & 1889 & 1890 & 1891 & 1892 & 1893 & 1894 \\
\hline Revenue-Passengers & $1,210,517$ & $1,573,271$ & $1,498,815$ & $1,459,332$ & $1,359,152$ & $1,219,102$ \\
\hline Revenue-Freight & $3,182,145$ & $3,430,446$ & $3,290,443$ & $3,127,291$ & $2,963,307$ & $2,656,819$ \\
\hline Revenue-Mail, etc. & 519,473 & 596,996 & $1,158,101$ & $1,358,160$ & 823,158 & 879,181 \\
\hline Total Revenue & $4,912,136$ & $5,600,713$ & $5,947,359$ & $5,944,783$ & $5,145,617$ & $4,755,102$ \\
\hline Maintenance of Road & 683,211 & 774,834 & 499,227 & 455,689 & 622,220 & 654,423 \\
\hline Maintenance of Equipment & $1,086,856$ & $1,152,919$ & $1,227,043$ & $1,185,471$ & $1,337,190$ & $1,211,504$ \\
\hline Other Operating Expenses & $1,151,272$ & $1,183,698$ & $1,211,352$ & $1,355,969$ & $1,360,903$ & $1,441,234$ \\
\hline Operating Expenses & $2,921,339$ & $3,111,451$ & $2,937,622$ & $2,997,129$ & $3,320,313$ & $3,307,161$ \\
\hline Operating Income & $1,990,797$ & $2,489,262$ & $3,009,737$ & $2,947,654$ & $1,825,304$ & $1,447,941$ \\
\hline Other Income (Loss) & 340,708 & $(188,896)$ & $(116,516)$ & $(117,843)$ & 0 & 0 \\
\hline Total Income & $2,331,505$ & $2,300,366$ & $2,893,221$ & $2,829,811$ & $1,825,304$ & $1,447,941$ \\
\hline Taxes* & 0 & 0 & 0 & 89,414 & 83,973 & 0 \\
\hline Rents & 834,500 & 851,500 & 851,500 & 851,500 & 834,500 & 834,500 \\
\hline Interest & 700,498 & 710,398 & 802,198 & 919,528 & $1,004,765$ & $1,006,689$ \\
\hline Other fixed charges $* *$ & 7,379 & $(12,407)$ & 71,521 & $(10,276)$ & $(200,778)$ & $(109,403)$ \\
\hline Fixed Charges & $1,542,377$ & $1,549,491$ & $1,725,219$ & $1,760,752$ & $1,638,487$ & $1,731,786$ \\
\hline Dividends & 500,000 & 500,000 & 500,000 & 500,000 & 0 & 0 \\
\hline Surplus & 289,128 & 250,875 & 668,002 & 479,645 & 102,844 & $(283,845)$ \\
\hline
\end{tabular}

*when reported, otherwise included in other operating expenses.

**this figure is simply the difference between fixed charges reported by the company and estimates of its rent and interest expenses based on its outstanding bonds and lease agreements. 
Table 2: Balance Sheets for years ending June $30^{\text {th }}$

\begin{tabular}{|c|c|c|c|c|c|c|}
\hline \\
\hline & 1883 & 1884 & 1885 & 1886 & 1887 & 1888 \\
\hline \multicolumn{7}{|l|}{ ASSETS } \\
\hline Fixed Assets & $13,446,726$ & $13,879,690$ & $16,307,708$ & $15,497,303$ & $16,334,491$ & $18,683,520$ \\
\hline Working Assets & 938,727 & 897,938 & 958,040 & $3,663,306$ & $3,201,062$ & $3,157,192$ \\
\hline Total & $14,385,453$ & $14,777,628$ & $17,265,748$ & $19,160,609$ & $19,535,553$ & $21,840,712$ \\
\hline \multicolumn{7}{|c|}{ LIABILITIES AND NET WORTH } \\
\hline Capital Stock & $5,000,000$ & $5,000,000$ & $5,000,000$ & $5,000,000$ & $5,000,000$ & $5,000,000$ \\
\hline Funded Debt & $6,712,150$ & $7,032,150$ & $9,381,500$ & $9,464,400$ & $10,196,300$ & $11,772,220$ \\
\hline Working Liabilities & $1,676,512$ & $1,635,924$ & $1,523,939$ & $3,164,874$ & $2,430,064$ & $2,682,001$ \\
\hline Profit \& Loss & 996,791 & $1,109,554$ & $1,360,309$ & $1,531,335$ & $1,909,189$ & $2,386,491$ \\
\hline \multirow[t]{2}{*}{ Total } & $14,385,453$ & $14,777,628$ & $17,265,748$ & $19,160,609$ & $19,535,553$ & $21,840,712$ \\
\hline & 1889 & 1890 & 1891 & 1892 & 1893 & 1894 \\
\hline \multicolumn{7}{|l|}{ ASSETS } \\
\hline Fixed Assets & $19,312,142$ & $22,300,909$ & $25,465,605$ & $30,793,157$ & $31,555,602$ & $32,825,467$ \\
\hline Working Assets & $3,439,172$ & $3,296,939$ & $4,165,391$ & $4,285,763$ & $3,611,549$ & $2,492,944$ \\
\hline Total & $22,751,314$ & $25,597,848$ & $29,630,996$ & $35,078,920$ & $35,167,151$ & $35,318,411$ \\
\hline \multicolumn{7}{|c|}{ LIABILITIES AND NET WORTH } \\
\hline Capital Stock & $5,000,000$ & $5,000,000$ & $5,000,000$ & $5,000,000$ & $5,000,000$ & $5,000,000$ \\
\hline Funded Debt & $12,138,040$ & $13,428,160$ & $14,171,160$ & $16,341,160$ & $18,167,705$ & $18,826,002$ \\
\hline Working Liabilities & $3,004,271$ & $4,397,609$ & $6,946,583$ & $9,660,089$ & $10,036,483$ & $8,501,732$ \\
\hline Profit \& Loss & $2,609,003$ & $2,772,079$ & $3,513,253$ & $4,077,671$ & $1,962,963$ & $2,990,677$ \\
\hline Total & $22,751,314$ & $25,597,848$ & $29,630,996$ & $35,078,920$ & $35,167,151$ & $35,318,411$ \\
\hline
\end{tabular}

Table 3: Operating Statistics for years ending June $30^{\text {th }}$ (Passenger-miles and ton-miles in thousands)

\begin{tabular}{|l|r|r|r|r|r|r|}
\hline & $\mathbf{1 8 8 3}$ & $\mathbf{1 8 8 4}$ & $\mathbf{1 8 8 5}$ & $\mathbf{1 8 8 6}$ & $\mathbf{1 8 8 7}$ & $\mathbf{1 8 8 8}$ \\
\hline Miles of Road & 2,514 & 2,617 & 2,617 & 2,336 & 2,336 & 2,336 \\
\hline Locomotives & 123 & 126 & 126 & 150 & 150 & 150 \\
\hline Passenger Cars & 96 & 100 & 100 & 105 & 105 & 105 \\
\hline Freight Cars & 2,316 & 2,351 & 2,351 & 2,525 & 2,525 & 2,525 \\
\hline Passenger-miles & 30,965 & 32,346 & 30,716 & 29,030 & 28,528 & 38,099 \\
\hline Per Pass-mile $(\phi)$ & 2.94 & 2.95 & 3.21 & 3.44 & 3.57 & 3.13 \\
\hline Ton-miles & 125,513 & 120,017 & 132,556 & 137,533 & 153,867 & 207,315 \\
\hline Per Ton-mile $(\phi)$ & 2.08 & 2.09 & 2.01 & 1.92 & 1.77 & 1.37 \\
\hline & $\mathbf{1 8 8 9}$ & $\mathbf{1 8 9 0}$ & $\mathbf{1 8 9 1}$ & $\mathbf{1 8 9 2}$ & $\mathbf{1 8 9 3}$ & $\mathbf{1 8 9 4}$ \\
\hline Miles of Road & 3,077 & 3,202 & 3,232 & 3,226 & 3,311 & 3,244 \\
\hline Locomotives & 158 & 195 & 232 & 384 & 381 & 325 \\
\hline Passenger Cars & 118 & 246 & 270 & 314 & 329 & 266 \\
\hline Freight Cars & 3,363 & 3,355 & 4,670 & 9,678 & 9,651 & 8,740 \\
\hline Passenger-miles & 27,696 & 32,346 & 35,785 & 36,023 & 35,332 & 31,976 \\
\hline Per Pass.-mile $(\phi)$ & 4.37 & 4.86 & 4.19 & 4.05 & 3.85 & 3.81 \\
\hline Ton-miles & 243,886 & 258,669 & 274,521 & 275,938 & 298,969 & 268,003 \\
\hline Per Ton-mile $(\phi)$ & 1.30 & 1.33 & 1.20 & 1.13 & 0.99 & 0.99 \\
\hline
\end{tabular}

\section{RAILROAD REORGANIZATION, $19^{\mathrm{TH}}$ CENTURY STYLE}

While revenue and income had been generally increasing for the Terminal Co. through the early 1890 s, examination of the operating statistics of the R\&D, shown in Table 3, reveals a troubling development. While the physical volume of business (i.e., passengers-miles and freight ton-miles) was growing strongly, freight rates were on the decline, as eventually would be passenger rates. For reasons beyond the scope of this case, the country was experiencing a long, gradual deflation, making debt and other fixed-dollar obligations increasingly burdensome.

For a time, the Terminal Co. outpaced the deflation by expanding its physical volume of business and by reducing unit costs through productivity-increasing investments. Eventually, however, the deflation so burdened debtors - whether farmers, railroads or banks - that productivity growth was insufficient to prevent default. And, 
upon an uptick in defaults and widespread concern for the solvency of debtors, came the bank panics and financial crises characteristic of that time.

Not only the Terminal Co., but many other great and not so great railroads were forced into receiverships during the late $19^{\text {th }}$ century. Among these were the Baltimore \& Ohio RR and Reading RR (two of the four railroads on the Monopoly game board), the Central Pacific RR and Union Pacific RR (which together formed the nation's first transcontinental railroad), the Norfolk \& Western Railway, and the Atchison, Topeka \& Santa Fe RR.

Typically, in railroad receiverships of the late $19^{\text {th }}$ century, a new company was organized to acquire the assets of the failed company, following a reorganization plan that respected the priority of claim of the securities that had been issued by the failed company (Hansen, 2000; Martin, 1974; Swain, 1898). (Some changes have occurred in corporate bankruptcies over the years; e.g., assessments are today rare.) During the time it took for the new company to be organized and for a proposed reorganization plan to be developed and gain sufficient acceptance by creditors, the railroad was operated by a court-appointed receiver, not unusually the president of the failed company. In most of these reorganizations:

1. Well-secured bonds of the failed company were simply assumed, undisturbed, by the new company.

2. Intermediate securities might suffer a small loss, such as being exchanged for new securities that pay interest or dividends only if earned (e.g., income bonds, which pay interest only if the income of the company is sufficient).

3. Some inferior securities might be exchanged for new securities only upon the payment of a cash assessment as was needed by the new company to restore the road and equipment inherited from the failed company to good working order, to pay interest arrears on well-secured bonds, and to pay the failed company's receiver's certificates and floating debt.

4. Some inferior securities might be completely wiped out.

To illustrate, consider a small railroad company that had issued $\$ 1$ million of 5 percent $1^{\text {st }}$ mortgage bonds, $\$ 1$ million of 5 percent $2^{\text {nd }}$ mortgage bonds, and $\$ 1$ million of stock, which had earnings of $\$ 75,000$ per year (which amount would be insufficient to pay interest on both the $1^{\text {st }}$ and $2^{\text {nd }}$ mortgage bonds), and which had developed a floating debt of $\$ 100,000$.

One possible reorganization plan for this company would be for a proposed new company to assume the failed company's $1^{\text {st }}$ mortgage bonds, and to offer $\$ 1,0005$ percent income bonds in the new company plus ten shares of stock in the new company, each having a par value of $\$ 100$, for $\$ 100$ cash plus $\$ 1,0002^{\text {nd }}$ mortgage bonds of the failed company. Notice that, in this reorganization, the stock of the failed company would be wiped out.

Another possible reorganization plan would be for a proposed new company to assume the failed company's $1^{\text {st }}$ mortgage bonds (as in the first plan), to exchange $\$ 1,000$ of 5 percent income bonds in the new company for $\$ 1,0005$ percent $2^{\text {nd }}$ mortgage bonds in the failed company, and to offer shares of stock in the new company, having a par value of $\$ 100$ each, for $\$ 10$ cash plus $\$ 100$ par value of shares in the failed company, to the holders of the failed company's stock. Notice that, in this alternate reorganization, the stockholders of the failed company are not completely wiped out, but they do have to advance the cash necessary to pay off the floating debt of the failed company.

If the stockholders of the failed company believe that the revenue and income will recover, then paying the $\$ 10$ per share assessment might appear to be attractive. With the assessment, they would "redeem" the company by paying off the floating debt, and - assuming that the revenue and income of the company do indeed recover - the company should be able to pay the full 5 percent interest on its new income bonds, and even pay dividends on its new stock.

The problem with this stockholder-friendly reorganization plan is that if the holders of the failed company's $2^{\text {nd }}$ mortgage bonds aren't satisfied with the exchange of their bonds for income bonds, they could make an alternative proposal, e.g., the first, in which they redeem the company. Generally, any class of creditors that would suffer a loss in a bankruptcy plan has the option of proposing a plan of its own. This motivates the directors and 
officers of the failed company, representing the interests of the shareholders of the failed company, to make an offer that treats all classes of creditors fairly, given their priorities of claim and a reasonable estimate of the company's earning power upon its reorganization.

Table 4 details the claims structure of the R\&D and its leased roads as of 1894 . Direct obligations of the company amount to $\$ 18.9$ million in debt and $\$ 5$ million in equity. Indirect obligations of the company, the interest and dividend payments on which were all guaranteed as part of the leases involved, amount to another \$12.6 million.

Table 4: Claims Structure of the Richmond \& Danville RR, 1894

\begin{tabular}{|c|c|c|c|c|}
\hline Security & Amount & $\mathbf{1}^{\text {st }}$ Mortgage* & $2^{\text {nd }}$ Mortgage* & $3^{\text {rd }}$ Mortgage* \\
\hline \multicolumn{5}{|l|}{ BALANCE SHEET } \\
\hline Receiver's certificates & $1,696,020$ & & & \\
\hline Richmond \& Danville eq 5s 1909 & $1,582,000$ & Equipment & & \\
\hline Richmond \& Danville eq 6s 1906 & 909,000 & Equipment & & \\
\hline other equipment trusts & 746,822 & Equipment & & \\
\hline Richmond \& Danville gen 6s 1915 & $5,996,000$ & 152 & 0 & 0 \\
\hline Richmond \& Danville deb 6s 1927 & $3,368,000$ & 0 & 152 & 0 \\
\hline Richmond \& Danville cons 5s 1936 & $4,528,160$ & 0 & 0 & 152 \\
\hline Richmond \& Danville stk & $5,000,000$ & & & \\
\hline \multicolumn{5}{|l|}{ LEASED LINES } \\
\hline Atlanta \& Charlotte. 1st 7s 1907 & $4,750,000$ & 339 & 0 & 0 \\
\hline Atlanta \& Charlotte. inc 6s 1900 & 750,000 & 0 & 339 & 0 \\
\hline Atlanta \& Charlotte. 5\% stk & $1,700,000$ & 0 & 0 & 339 \\
\hline North Carolina $61 / 2 \%$ stk & $4,000,000$ & 233 & 0 & 0 \\
\hline Piedmont 1st 8s 1894 & 400,000 & 49 & 0 & 0 \\
\hline Piedmont 2nd 6s 1900 & 500,000 & 0 & 49 & 0 \\
\hline Piedmont $6 \%$ stk & 500,000 & 0 & 0 & 49 \\
\hline
\end{tabular}

*miles of railroad unless otherwise stated

\section{MANAGEMENT'S PLAN}

Mr. Inman was determined that, if possible, the shareholders would redeem the R\&D, the strongest component of the Terminal Co., and the incumbent directors and officers would remain in place. Furthermore, if the R\&D could be reorganized by management, it might be possible that most, if not all of the other roads in the system could be salvaged, preserving the fortunes of those who had invested heavily in the junior securities of the system (this would include preserving his own fortune). Unfortunately, the shareholders of the company had very little cash with which to redeem the company. A reorganization plan for the R\&D required the following:

1. $\$ 3$ to 5 million in cash to pay off the receiver's certificates and reduce the company’s working liabilities to a manageable level.

2. Reduce the company's fixed charges by at least $\$ 300,000$ so as to enable it to avoid another default if the depression were to continue.

The plan developed by management consisted, basically, of three parts: (1) Ten percent assessments on all classes of credit and on equity, in order to raise $\$ 3.5$ million in cash; (2) Using the $\$ 3.5$ million to pay off $\$ 1.7$ million of receiver's certificates and reduce the company's working liabilities by $\$ 1.8$ million; and, (3) converting the fixed interest and rent obligations on the third mortgage claims of the company and its leased roads into obligations contingent on the earnings of the company, thus reducing the company's fixed charges by a little more than $\$ 300,000$ (see Table 5). 
Table 5: Management's Reorganization Plan

\begin{tabular}{|l|r|r|r|r|r|}
\hline \multicolumn{1}{|c|}{ Security } & \multicolumn{1}{c|}{ Amount } & \multicolumn{1}{c|}{ Assessment } & \multicolumn{2}{c|}{ Disposition } & \multicolumn{2}{c|}{ Fixed Charges } \\
\hline BALANCE SHEET & & $\mathbf{1 0 \%}$ each & & \multicolumn{1}{c|}{ After } \\
\hline Receiver's certificates & $1,696,020$ & & Paid off & 79,100 & 79,100 \\
\hline R\&D eq 5s 1909 & $1,582,000$ & 158,200 & Assumed & 54,540 & 54,540 \\
\hline R\&D eq 6s 1906 & 909,000 & 90,900 & Assumed & 44,809 & 44,809 \\
\hline other equipment trusts & 746,822 & 74,682 & Assumed & 359,760 & 359,760 \\
\hline R\&D gen 6s 1915 & $5,996,000$ & 599,600 & Assumed & 202,080 & 202,080 \\
\hline R\&D deb 6s 1927 & $3,368,000$ & 336,800 & Assumed & 226,408 & 0 \\
\hline R\&D cons 5s 1936 & $4,528,160$ & 452,816 & Exch for income bonds & 0 \\
\hline Richmond \& Danville stk & $5,000,000$ & 500,000 & Assumed & 332,500 & 332,500 \\
\hline LEASED LINES & & & & 45,000 & 45,000 \\
\hline Atlanta \& Charlotte 1st 7s & $4,750,000$ & 475,000 & Assumed & 85,000 & 85,000 \\
\hline Atlanta \& Charlotte inc 6s & 750,000 & 75,000 & Assumed & 260,000 & 260,000 \\
\hline Atlanta \& Charlotte 5\% stk & $1,700,000$ & 170,000 & Div contingent on income & 32,000 & 32,000 \\
\hline North Carolina 61/2\% stk & $4,000,000$ & 400,000 & Assumed & 30,000 & 30,000 \\
\hline Piedmont 1st 8s 1894 & 400,000 & 40,000 & Assumed & 30,000 & \\
\hline Piedmont 2nd 6s 1900 & 500,000 & 50,000 & Assumed & 0 \\
\hline Piedmont 6\% stk & 500,000 & 50,000 & Div contingent on income & $1,781,197$ & $1,439,789$ \\
\hline TOTALS & & $3,472,998$ & & &
\end{tabular}

\section{ENTER J.P. MORGAN}

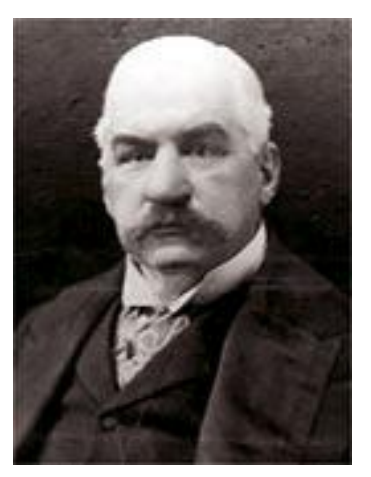

By the 1890s, J.P. Morgan had established himself as the most powerful investment banker in the world. During that decade, he was instrumental in the reorganization of several large railroad systems, and even in helping the U.S. government maintain the gold standard. He later became associated with the organization of several large "trusts," or industrial monopolies, including U.S. Steel. Mr. Morgan seemed to enjoy both making money and using his wealth to pursue science, the arts, and beauty. His many benefactions include the Morgan collection of gems at the Metropolitan Museum of Natural History, and the founding of the Metropolitan Museum of Art. But, no matter how intelligent, witty, rich and powerful he was, he still had a big ugly nose.

The reorganization plan for the $\mathrm{R} \& \mathrm{D}$ proposed by management seemed to $\mathrm{Mr}$. Morgan to both undervalue the earning ability of the railroad upon a turn-around of the economy, and impose too severe a loss to the bondholders of the company. Mr. Morgan was committed to the principle that bondholders were to be protected from risk in accordance with their priority of claim, and that railroads should be run for the benefit of all their stakeholders, paying good wages to workers, lowering fares to shippers, and making a good rate of return for their investors. His commitment to these principles gained for his banking house the trust of individual investors, insurance companies and banks in the advanced economies of the world, and enabled him to raise enormous amounts of money on reasonable terms.

In looking at a company like the $\mathrm{R} \& \mathrm{D}$, having an immediate need for a substantial amount of cash, Mr. Morgan could consider the possibility of raising funds by the sale of stock in the new company at a price reflecting reasonable estimates of the future earnings of the company assuming economic recovery.

Indeed, this is exactly what Mr. Morgan wants you to help him with. He wants you to develop an alternative reorganization plan to be put forward on behalf of the several classes of bondholders of the company. In this alternative plan, the cash needed to reorganize the company is to come from wiping out the stock of the failed company, and selling stock in the new company to a syndicate of investors. Remember, that all classes of bondholders must receive at least what is offered to them in the plan proposed by management, and that the amount offered to each class of creditor must (in this case and almost always) respect priority of claim. 


\section{AUTHOR INFORMATION}

Clifford F. Thies is the Eldon R. Lindsay Chair of Free Enterprise and Professor of Economics and Finance at Shenandoah University. He received his B.A. in mathematics and M.B.A. from St. John's University, New York, and his Ph.D. in economics from Boston College. He previously taught at the University of Baltimore and the University of Montana, and has been a systems analyst with AIG and an infantry officer in the U.S. Army. He and his wife, Barbara, enjoy traveling, nature photography and collecting financial memorabilia.

\section{REFERENCES}

1. Stuart Daggett, “Southern Railway,” pp. 146-91. In Railroad Reorganization. Cambridge, MA: Harvard University Press, 1908.

2. Bradley Hansen, "The People's Welfare and the Origins of Corporate Reorganization: The Wabash Receivership Reconsidered." Business History Review 74 (Autumn 2000): 377-405

3. Maury Klein, The Great Richmond Terminal: A Study in Businessmen and Business Strategy. Charlottesville, VA: University of Virginia Press. 1970.

4. Albro Martin, "Railroads and the Equity Receivership: An Essay on Institutional Change." Journal of Economic History 34 (1974): 685-709.

5. Henry Poor, Manual of Railroads. New York: H.V. and H.W. Poor, 1884-1895.

6. John Stover, The Railroads of the South, 1865-1900. Chapel Hill, NC: University of North Carolina Press, 1955.

7. Henry Huntington Swain, "Economic Aspects of Railroad Receivership.” Economic Studies of the American Economic Association 3 (1898): 53-161.

8. Peter Tufano, "Business Failure, Judicial Intervention, and Financial Innovation: Restructuring U. S. Railroads in the Nineteenth Century." Business History Review 71 (Spring 1997): 1-40. 
NOTES 